\title{
Front Matter: Volume 9066
}

, "Front Matter: Volume 9066," Proc. SPIE 9066, Eleventh International Conference on Correlation Optics, 906601 (3 January 2014); doi: $10.1117 / 12.2053584$

SPIE Event: Eleventh International Conference on Correlation Optics, 2013, SPIE. Chernivsti, Ukraine 


\title{
PROCEEDINGS OF SPIE
}

\section{Eleventh International Conference on Correlation Optics}

\author{
Oleg V. Angelsky \\ Editor
}

\section{8-21 September 2013 Chernivtsi, Ukraine}

\section{Organized by}

International Commission for Optics • EOS_European Optical Society • OSA-The Optical Society • EPS_European Physical Society • USPAO_The Ukrainian Society of Pure and Applied Optics (Ukraine) • Yuriy Fedkovych Chernivtsi National University (Ukraine) • Chernivtsi Regional State Administration, Institute of Postdiploma Pedagogical Education (Ukraine) • Rhythm Optoelectronics, Inc. (Ukraine)

Sponsored by

OSA-The Optical Society • EPS—European Physical Society • International Commission for Optics • EOS-European Optical Society • European Office of Aerospace Research and Development • United States Air Force Office of Scientific Research • United States Air Force Research Laboratory • Rhythm Optoelectronics, Inc. (Ukraine) • The Oculus Microsurgery Clinic "Vash Zir" (Ukraine) • Defis Ltd. (Ukraine) • Privatbank (Ukraine) • Arton Company (Ukraine)

Cooperating Organization and Publisher

SPIE

\section{Volume 9066}


The papers included in this volume were part of the technical conference cited on the cover and title page. Papers were selected and subject to review by the editors and conference program committee. Some conference presentations may not be available for publication. The papers published in these proceedings reflect the work and thoughts of the authors and are published herein as submitted. The publisher is not responsible for the validity of the information or for any outcomes resulting from reliance thereon.

Please use the following format to cite material from this book:

Author(s), "Title of Paper," in Eleventh International Conference on Correlation Optics, edited by Oleg V. Angelsky, Proceedings of SPIE Vol. 9066 (SPIE, Bellingham, WA, 2013) Article CID Number.

ISSN: 0277-786X

ISBN: 9780819499936

Published by

SPIE

P.O. Box 10, Bellingham, Washington 98227-0010 USA

Telephone +1 3606763290 (Pacific Time) · Fax +1 3606471445

SPIE.org

Copyright (C) 2013, Society of Photo-Optical Instrumentation Engineers.

Copying of material in this book for internal or personal use, or for the internal or personal use of specific clients, beyond the fair use provisions granted by the U.S. Copyright Law is authorized by SPIE subject to payment of copying fees. The Transactional Reporting Service base fee for this volume is $\$ 18.00$ per article (or portion thereof), which should be paid directly to the Copyright Clearance Center (CCC), 222 Rosewood Drive, Danvers, MA 01923. Payment may also be made electronically through $\mathrm{CCC}$ Online at copyright.com. Other copying for republication, resale, advertising or promotion, or any form of systematic or multiple reproduction of any material in this book is prohibited except with permission in writing from the publisher. The CCC fee code is $0277-786 \mathrm{X} / 13 / \$ 18.00$.

Printed in the United States of America.

Publication of record for individual papers is online in the SPIE Digital Library.

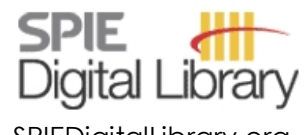

SPIEDigitalLibrary.org

Paper Numbering: Proceedings of SPIE follow an e-First publication model, with papers published first online and then in print and on CD-ROM. Papers are published as they are submitted and meet publication criteria. A unique, consistent, permanent citation identifier (CID) number is assigned to each article at the time of the first publication. Utilization of CIDs allows articles to be fully citable as soon as they are published online, and connects the same identifier to all online, print, and electronic versions of the publication. SPIE uses a six-digit CID article numbering system in which:

- The first four digits correspond to the SPIE volume number.

- The last two digits indicate publication order within the volume using a Base 36 numbering

system employing both numerals and letters. These two-number sets start with 00, 01, 02, 03, 04,

$05,06,07,08,09,0 A, 0 B \ldots$. OZ, followed by 10-1Z, 20-2Z, etc.

The CID Number appears on each page of the manuscript. The complete citation is used on the first page, and an abbreviated version on subsequent pages. Numbers in the index correspond to the last two digits of the six-digit CID Number. 


\title{
Contents
}

\author{
xi Conference Committee \\ $\mathrm{xv}$ Introduction
}

SESSION 1 INFORMATIVE CONTENT OF STATISTICAL OPTICAL FIELDS, INCLUDING OPTICAL CHAOS, SINGULAR OPTICS, POLARIZATION OPTICS AND COHERENCE

906602 Transverse energy redistribution upon edge diffraction of a paraxial laser beam with optical vortex [9066-47]

A. Bekshaev, K. A. Mohammed, Odessa I.I. Mechnikov National Univ. (Ukraine)

906603 Recent progress in statistical information optics: statistical information processing for optics [9066-97]

W. Wang, J. Zhao, Heriot-Watt Univ. (United Kingdom); M. Takeda, Utsunomiya Univ. (Japan)

906604 Stochastic singular optics [9066-1]

F. S. Roux, CSIR National Laser Ctr. (South Africa)

906605 Determination of $U$ contours in simulated speckle fields [9066-2]

Ch. Felde, M. V. Oleksyuk, Yuriy Fedkovych Chernivtsi National Univ. (Ukraine)

906606 Statistical properties of Stokes parameters in polarization speckle generated from a rough surface scattering [9066-3]

S. Zhang, W. Wang, Heriot-Watt Univ. (United Kingdom)

906607 Investigation of correlation properties of light fields by Fresnel diffraction from a step [9066-46]

S. R. Hosseini, M. T. Tavassoly, Univ. of Tehran (Iran, Islamic Republic of)

906608 The model realizations of unconventional polarization states and estimation of coherent properties of optical fields [9066-52]

N. Gorodynska, Yuriy Fedkovych Chernivtsi National Univ. (Ukraine)

906609 Global "correlation" between parameters of optical field [9066-99]

I. Mokhun, Yu. Galushko, Ye. Kharitonova, Yu. Viktorovskaya, Yuriy Fedkovych Chernivtsi National Univ. (Ukraine)

$90660 \mathrm{~A} \quad$ Singular phase elements as detectors for different polarizations [9066-27] S. N. Khonina, D. A. Savelyev, N. L. Kazansky, V. A. Soifer, Image Processing Systems Institute (Russian Federation)

9066 OB Propagation optical quarks after an uniaxial crystal: the experiment [9066-42] Yu. A. Egorov, V. L. Konovalenko, A. O. Zinovev, P. M. Anischenko, M. V. Glumova, Taurida National V.I. Vernadsky Univ. (Ukraine) 
$90660 \mathrm{C}$ Algebra of optical quarks: an experiment [9066-43]

Y. Egorov, V. Konovalenko, A. Zinovev, M. Nesterova, M. Glumova, Taurida National

V.I. Vernadsky Univ. (Ukraine)

9066 OD Evolution of symmetric and asymmetric optical beam arrays passing along optical axis of uniaxial crystal [9066-49]

T. Fadeyeva, M. Ivanov, K. Borysova, A. Borysov, A. Rubass, Taurida National V.I. Vernadsky Univ. (Ukraine)

9066 OE The evolution of light spin-orbital momentum within the rotated uniaxial crystal near the perpendicular to its optical axis [9066-56]

B. V. Sokolenko, A. F. Rubass, S. N. Lapaeva, M. V. Glymova, A. V. Volyar, Taurida National V.I. Vernadsky Univ. (Ukraine)

9066 OF Diagnostics of optical fields and media in the framework of the polarization approaches [9066-21]

I. V. Soltys, Yuriy Fedkovych Chernivtsi National Univ. (Ukraine)

9066 OG Generation of fractional optical vortices at the edge of the phase wedge [9066-50]

A. Kovalyova, A. Markovskyy, T. Fadeyeva, A. Rubass, Taurida National V.I. Vernadsky Univ. (Ukraine)

SESSION 2 OPTICAL CORRELATION DEVICES BASED ON DIFFRACTIVE OPTICAL ELEMENTS, INCLUDING OPTICAL AND DIGITAL HOLOGRAPHY, FRACTAL OPTICS, OPTICAL SENSORS

$9066 \mathrm{OH} \quad$ Optical correlation aspect of holography: from ghost-imaging to static phase-conjugation holographic associative memories [9066-101]

P. V. Polyanskii, Yuriy Fedkovych Chernivtsi National Univ. (Ukraine); Ye. M. Husak,

Bukovinian Univ. (Ukraine)

9066 Ol Novel imaging spectrometers and polarimeters [9066-33]

E. L. Dereniak, College of Optical Sciences, The Univ. of Arizona (United States)

$90660 \mathrm{~J} \mathrm{Moving} \mathrm{average} \mathrm{process} \mathrm{underlying} \mathrm{the} \mathrm{holographic-optical-tweezers} \mathrm{experiments}$ [9066-5]

J. Ślęzak, S. Drobczyński, K. Weron, J. Masajada, Wrocław Univ. of Technology (Poland)

9066 OK Denoising and extracting background from fringe patterns using midpoint-based bidimensional empirical mode decomposition [9066-8]

M. Wielgus, K. Patorski, Warsaw Univ. of Technology (Poland)

$9066 \mathrm{OL}$ Singularities in the interference field of the three beam interferometer [9066-44]

P. Kurzynowski, M. Zdunek, Wrocław Univ. of Technology (Poland)

9066 0M Geometrical noise bandwidth of thermal imager with matrix detector [9066-40]

V. G. Kolobrodov, National Technical Univ. of Ukraine (Ukraine)

$90660 \mathrm{~N}$ The problems of designing coherent spectrum analyzers [9066-41]

V. G. Kolobrodov, G. S. Tymchik, Q. A. Nguyen, National Technical Univ. of Ukraine (Ukraine) 
906600 Three dimensional point spread function of an optical system and its approximation [9066-48]

V. Borovytsky, V. Chorna, A. Fesenko, National Technical Univ. of Ukraine (Ukraine)

9066 OP Experimental realization of an axial optical vortex beam synthesis using a Gaussian beam and two ramps from a spatial light modulator [9066-31]

A. N. Khoroshun, A. V. Chernykh, A. N. Tsimbaluk, J. A. Kirichenko, East Ukrainian National Univ. (Ukraine); P. V. Yezhov, Institute of Physics (Ukraine); J.-T. Kim, Chosun Univ. (Korea, Republic of)

$90660 Q \quad$ Formation of a ring dislocation of a coherence of a vortex optical beam in turbulent atmosphere [9066-39]

I. P. Lukin, V.E. Zuev Institute of Atmospheric Optics (Russian Federation)

9066 OR Role of diffraction grating profile in the wavefront sensor based on the Talbot effect [9066-82]

A. V. Kovalenko, M. M. Kotov, V. N. Kurashov, M. M. Movchan, Taras Shevchenko National Univ. of Kyiv (Ukraine)

9066 OS Influence of aperture size on wavefront sensor based on the Talbot effect [9066-85]

D. V. Podanchuk, M. M. Kotov, A. A. Goloborodko, V. N. Kurashov, V. P. Dan'ko,

A. V. Kurashov, Taras Shevchenko National Univ. of Kyiv (Ukraine)

9066 OT Investigation of Cauchy and nonlocal problems of diffusion equation [9066-30]

V. V. Gorodetsky, Ya. M. Drin, Yuriy Fedkovych Chernivtsi National Univ. (Ukraine) and Bukovina State Finance and Economics Univ. (Ukraine)

9066 OU Nonlocal problem for one class equations of diffusion in space of generalized functions [9066-55]

Ya. M. Drin, Bukovina State Finance and Economics Univ. (Ukraine)

9066 OV Control over the sensitivity of a correlator in the method of synthesized phase objects [9066-28]

P. V. Yezhov, Institute of Physics (Ukraine); A. V. Kuzmenko, IC "Institute of Applied Optics" (Ukraine); J.-T. Kim, Chosun Univ. (Korea, Republic of); A. M. Sakharuk, L. I. Muravsky, Karpenko Physico-Mechanical Institute (Ukraine); T. N. Smirnova, Institute of Physics (Ukraine)

SESSION 3 OPTICAL CORRELATION DIAGNOSTICS, INTERFEROMETRY AND MICROSCOPY OF ROUGH SURFACES AND RANDOM MEDIA

9066 OW Diffusing low-coherence interferometry of turbid media: an approach to transport parameters evaluation [9066-84]

D. A. Zimnyakov, J. S. Sina, O. V. Ushakova, E. A. Isaeva, S. A. Yuvchenko, Saratov State Technical Univ. (Russian Federation); S. B. Yermolenko, P. V. Ivashko, Yuriy Fedkovych Chernivtsi National Univ. (Ukraine)

9066 OX Optical resonance on LIPSS sensed by polarized light [9066-4]

M. Silvennoinen, Univ. of Eastern Finland (Finland); S. Hasoň, Institute of Biophysics of the ASCR, v.v.i. (Czech Republic); R. Silvennoinen, Univ. of Eastern Finland (Finland) 
9066 OY Measurement of temperature and temperature distribution in diffusion flames using digital speckle pattern interferometry [9066-10]

M. Kumar, V. Kumar, C. Shakher, Indian Institute of Technology Delhi (India)

$90660 Z$ Optical testing of reflective surfaces [9066-14]

A. A. Goloborodko, National Taras Shevchenko Univ. of Kyiv (Ukraine)

906610 Stimulated diffusion light scattering on variations of particles concentration in liquids [9066-9]

I. S. Burkhanov, L. L. Chaikov, P. N. Lebedev Physical Institute (Russian Federation)

906611 Features of optical image jitter in a random medium with a finite outer scale [9066-35] L. A. Bolbasova, V. P. Lukin, V. V. Nosov, A. V. Torgaev, V.E. Zuev Institute of Atmospheric Optics (Russian Federation)

906612 Comparison of singular-optical and statistical approaches for investigations of turbulence tasks [9066-36]

V. P. Lukin, V.E. Zuev Institute of Atmospheric Optics (Russian Federation); O. V. Angelski, Yuriy Fedkovych Chernivtsi National Univ. (Ukraine); L. A. Bolbasova, E. A. Kopylov, M. V. Tuev, V. V. Nosov, V.E. Zuev Institute of Atmospheric Optics (Russian Federation)

$906613 \quad$ Light-induced hysteresis in spin crossover compounds under noise [9066-13] I. V. Gudyma, A. Iu. Maksymov, Yuriy Fedkovych Chernivtsi National Univ. (Ukraine)

906614 The effect of surface treatment on electrical and photoelectrical properies of anisotype heterojunctions n-TiN/p-Si [9066-16]

M. N. Solovan, V. V. Brus, P. D. Maryanchuk, Yuriy Fedkovych Chernivtsi National Univ. (Ukraine)

906615 Influence of mechanisms and kinetics of growing ZnO nanocrystals from oversaturated solutions on their optoelectronic properties [9066-17]

R. D. Vengrenovich, B. V. Ivanskii, I. I. Panko, M. O. Stasyk, I. V. Fesiv, Yuriy Fedkovych Chernivtsi National Univ. (Ukraine)

906616 Surface morphology, optical properties and sensing characteristics of ZnMeO (Me - Mn, Co, Ni ) thin films [9066-18]

P. M. Tkachuk, A. I. Savchuk, I. D. Stolyarchuk, G. I. Kleto, S. A. Savchuk, V. I. Tkachuk, Yuriy Fedkovych Chernivtsi National Univ. (Ukraine)

906617 Optical and magneto-optical properties of PbFel2 nanoparticles [9066-19]

I. D. Stolyarchuk, A. I. Savchuk, V. V. Makoviy, O. A. Shporta, O. A. Savchuk, Yuriy Fedkovych Chernivtsi National Univ. (Ukraine); I. Stefaniuk, I. Rogalska, Univ. of Rzeszow (Poland)

906618 Interaction of human serum albumin with CdTe quantum dots probed by optical spectroscopy methods [9066-24]

A. I. Savchuk, I. D. Stolyarchuk, Yuriy Fedkovych Chernivtsi National Univ. (Ukraine);

P. M. Grygoryshyn, O. P. Antonyuk, Bukovinian State Medical Univ. (Ukraine); T. A. Savchuk, Yuriy Fedkovych Chernivtsi National Univ. (Ukraine) 
906619 Oscillations in radiation spectrum of sequence of electrons moving in spiral in transparent medium [9066-25]

A. V. Konstantinovich, Yuriy Fedkovych Chernivtsi National Univ. (Ukraine);

I. A. Konstantinovich, Yuriy Fedkovych Chernivtsi National Univ. (Ukraine) and Institute of Thermoelectricity (Ukraine)

9066 1A Study of fractality of optical fields scattered by Brownian particles [9066-51]

A. P. Maksimyak, K. I. Shlamp, Yuriy Fedkovych Chernivtsi National Univ. (Ukraine)

9066 1B Multiple-wave diffraction in x-ray interferometers [9066-60]

M. Raransky, V. Balazyuk, M. Melnyk, O. Kniginitska, M. Gunko, Yuriy Fedkovych Chernivtsi

National Univ. (Ukraine); M. Kshevetska, Chernivtsi Trade and Economics Institute (Ukraine)

9066 1C Moire effects arising on mechanical treatment of single crystal surface [9066-61]

M. Raransky, V. Balazyuk, M. Melnyk, O. Kniginitska, M. Gunko, Yuriy Fedkovych Chernivtsi National Univ. (Ukraine)

9066 ID Polymer dispersed liquid crystals spectral filtering [9066-66]

P. P. Maksimyak, A. P. Maksimyak, A. L. Nehrych, Yuriy Fedkovych Chernivtsi National Univ. (Ukraine)

$9066 \mathrm{IE}$ Optical filters on the base of $(3 \mathrm{HgSe})_{0.5}\left(\ln _{2} \mathrm{Se}_{3}\right)_{0.5}$, doped with $\mathrm{Mn}$ or Fe [9066-68] I. P. Koziarskyi, E. V. Maistruk, D. P. Koziarskyi, Yuriy Fedkovych Chernivtsi National Univ. (Ukraine)

$9066 \mathrm{IF}$ Interference forming of transmission by polymer dispersed liquid crystals [9066-70] P. P. Maksimyak, A. L. Nehrych, Yuriy Fedkovych Chernivtsi National Univ. (Ukraine)

9066 1G Temperature and baric dependence of nuclear quadruple resonance spectra in indium and gallium monoselenides [9066-71]

V. Khandozhko, N. Raranskii, V. Balazjuk, A. Samila, Yuriy Fedkovych Chernivtsi National Univ. (Ukraine); Z. Kovalyuk, I.N. Frantsevich Institute for Problems in Materials Science (Ukraine)

$9066 \mathrm{1H}$ The spatial chaotization of the optical field scattered by liquid crystals [9066-78] M. S. Gavrylyak, P. P. Maksimyak, Yuriy Fedkovych Chernivtsi National Univ. (Ukraine); O. S. Kshevetsky, Chernivtsi Trade and Economics Institute (Ukraine)

$906611 \quad$ Photoacoustic investigations of cement hydration process [9066-79] M. P. Gorsky, A. P. Maksimyak, Yuriy Fedkovych Chernivtsi National Univ. (Ukraine)

$90661 \mathrm{~J}$ Dynamic coherent light scattering by the cement during hydration process [9066-105] M. P. Gorsky, P. P. Maksimyak, Yuriy Fedkovych Chernivtsi National Univ. (Ukraine)

$90661 \mathrm{~K}$ Self-focusing of laser beam in dispersed medium [9066-100]

O. V. Angelsky, V. R. Besaga, A. P. Maksimyak, Yuriy Fedkovych Chernivtsi National Univ. (Ukraine) 
9066 1L Nuclear fuel assemblies' deformations measurement by optoelectronic methods in cooling ponds [9066-90]

E. S. Senchenko, Technological Design Institute of Scientific Instrument Engineering (Russian Federation) and Novosibirsk State Technical Univ. (Ukraine); P. S. Zavyalov, L. V. Finogenov, D. R. Khakimov, Technological Design Institute of Scientific Instrument Engineering (Russian Federation)

$90661 \mathrm{M}$ Polarization-induced angular momentum of arbitrary light-scattering particle [9066-32] M. Yu. Sakhnovskii, V. M. Rudeychuk, P. V. Polyanskii, Yuriy Fedkovych Chernivtsi National Univ. (Ukraine)

\section{SESSION 4 NEW APPLICATIONS OF CORRELATION OPTICS IN BIOLOGY AND MEDICINE}

9066 iN Small angle scattering polarization biopsy: a comparative analysis of various skin diseases [9066-59]

D. A. Zimnyakov, M. V. Alonova, Saratov State Technical Univ. (Russian Federation);

S. B. Yermolenko, P. V. Ivashko, Yuriy Fedkovych Chernivtsi National Univ. (Ukraine);

E. M. Reshetnikova, E. M. Galkina, S. R. Utz, Saratov State Medical Univ. (Russian Federation)

906610 Information content of the space-frequency filtering of blood plasma layers laser images in the diagnosis of pathological changes [9066-86]

A. G. Ushenko, Yuriy Fedkovych Chernivtsi National Univ. (Ukraine); T. M. Boychuk,

O. P. Mincer, G. B. Bodnar, Bukovinian State Medical Univ. (Ukraine); L. Ya. Kushnerick, Yuriy Fedkovych Chernivtsi National Univ. (Ukraine); V. O. Savich, Bukovinian State Medical Univ. (Ukraine)

9066 IP Simulation of propagation of radiation in epithelial tissues [9066-62]

P. V. Ivashko, Yuriy Fedkovych Chernivtsi National Univ. (Ukraine); D. A. Zymnyakov, M. V. Alonova, Saratov State Technical Univ. (Russian Federation); I. Gruia, Univ. of Bucharest (Romania); M. I. Gruia, Oncologic Institute "Al. Trestioreanu" (Romania)

9066 1Q Macro- and microscopic spectral-polarization characteristics of the structure of normal and abnormally located chordae tendianeae of left ventricular [9066-69]

Yu. Yu. Malyk, Bukovinian State Medical Univ. (Ukraine); O. G. Prydij, Yuriy Fedkovych Chernivtsi National Univ. (Ukraine); D. A. Zymnyakov, M. V. Alonova, O. V. Ushakova, Saratov State Technical Univ. (Russian Federation)

9066 IR Morphology of chordae tendianeae of atrioventricular heart valves of newborns and infants in terms of laser polarimetry [9066-72]

N. P. Pentelejchuk, K. M. Chala, Bukovinian State Medical Univ. (Ukraine); S. B. Yermolenko, Yuriy Fedkovych Chernivtsi National Univ. (Ukraine)

9066 is Laser polarimetry in determining of anisotropic structure of the heart valves [9066-73] T. O. Semenyuk, O. I. Petryshen, Bukovinian State Medical Univ. (Ukraine); O. G. Prydij, Yuriy Fedkovych Chernivtsi National Univ. (Ukraine); I. Gruia, Univ. of Bucharest (Romania);

C. Gavrila, Technical Univ. of Civil Engineering Bucharest (Romania) 
9066 1T Comparison of absorption spectra of adenocarcinoma and squamous cell carcinoma cervical tissue [9066-74]

O. P. Peresunko, N. V. Zelinska, Bukovinian State Medical Univ. (Ukraine); O. G. Prydij, Yuriy Fedkovych Chernivtsi National Univ. (Ukraine); D. A. Zymnyakov, O. V. Ushakova, Saratov State Technical Univ. (Russian Federation)

$90661 \mathrm{U}$ The correlation-optical method measuring time of thrombus formation [9066-77] M. S. Gavrylyak, Yuriy Fedkovych Chernivtsi National Univ. (Ukraine); P. M. Grygoryshyn, Chernivtsi Medical Univ. (Ukraine)

$90661 \mathrm{~V} \quad$ Fourier analysis of blood plasma laser images phase maps in the diagnosis of cancer in human organs [9066-89]

P. O. Angelsky, L. Ya. Kushnerick, Yuriy Fedkovych Chernivtsi National Univ. (Ukraine); V. T. Bachinskiy, O. Ya. Vanchuliak, M. Garazdiuk, N. V. Pashkovska, D. Andriychuk, Bukovinian State Medical Univ. (Ukraine)

9066 1W Fractal structure of optical anisotropy Mueller-matrices images of biological layers [9066-91]

A. V. Dubolazov, Yuriy Fedkovych Chernivtsi National Univ. (Ukraine); G. D. Koval, Bukovinian State Medical Univ. (Ukraine); N. I. Zabolotna, S. V. Pavlov, Vinnytsia National Technical Univ. (Ukraine)

9066 1X Mueller-matrices polarization selection of two-dimensional linear and circular birefringence images [9066-92]

V. A. Ushenko, Yuriy Fedkovych Chernivtsi National Univ. (Ukraine); N. I. Zabolotna,

S. V. Pavlov, Vinnytsia National Technical Univ. (Ukraine); D. M. Burcovets,

O. Yu. Novakovska, Yuriy Fedkovych Chernivtsi National Univ. (Ukraine)

9066 1Y Multiparameter correlation microscopy of biological fluids polycrystalline networks [9066-93]

A. V. Dubolazov, V. Marchuk, O. I. Olar, V. T. Bachinskiy, O. Ya. Vanchuliak, N. V. Pashkovska, D. Andriychuk, S. V. Kostiuk, Yuriy Fedkovych Chernivtsi National Univ. (Ukraine)

$90661 \mathrm{~F}$ Fourier filtering of linear and circular birefringence in cancer diagnosis [9066-94] A. O. Karachevtsev, V. A. Ushenko, O. I. Olar, V. Marchuk, N. V. Pashkovska, D. Andriychuk, Yuriy Fedkovych Chernivtsi National Univ. (Ukraine)

906620 Polarization-phase tomography of biological fluids polycrystalline structure [9066-96] A. V. Dubolazov, O. Ya. Vanchuliak, M. Garazdiuk, M. I. Sidor, A. V. Motrich, S. V. Kostiuk, Yuriy Fedkovych Chernivtsi National Univ. (Ukraine)

$906621 \quad$ Mueller-matrix differential diagnosis of biological crystallites phase anisotropy [9066-98] V. O. Ushenko, G. D. Koval, V. T. Bachinskiy, L. Ya. Kushnerick, M. Garazdiyk, M. M. Dominikov, O. V. Dronenko, Yuriy Fedkovych Chernivtsi National Univ. (Ukraine)

906622 Polarization correlometry of birefringence images of human blood layers [9066-106] A. G. Ushenko, P. O. Angelsky, A. O. Karachevtsev, Yuriy Fedkovych Chernivtsi National Univ. (Ukraine); G. B. Bodnar, G. D. Koval, Bukovinian State Medical Univ. (Ukraine); O. G. Prydiy, Yuriy Fedkovych Chernivtsi National Univ. (Ukraine); Yu. Marchuk, Bukovinian State Medical Univ. (Ukraine) 
906623 Diagnostic value spectropolarimetry of blood plasma in patients with sporadic and family breast cancer [9066-67]

O. P. Peresunko, T. V. Kruk, Bukovinian State Medical Univ. (Ukraine); S. B. Yermolenko, Yuriy Fedkovych Chernivtsi National Univ. (Ukraine)

Author Index 


\title{
Conference Committee
}

\author{
Conference Chair
}

Oleg V. Angelsky, Chernivtsi National University (Ukraine)

\section{Conference Cochairs}

Roman M. Besaha, Chernivtsi National University (Ukraine)

Alexander G. Ushenko, Chernivtsi National University (Ukraine)

\section{Program Committee}

Oleg V. Angelsky, Chernivtsi National University (Ukraine)

M. Alonso, Institute of Optics at the University of Rochester (United States)

P. Ambs, Université of Haute Alsace (France)

Gert von Bally, Universität Münster (Germany)

M. Berry, University of Bristol (United Kingdom)

K. Bliokh, Australian National University (Australia)

M. Calvo, La Universidad Complutense de Madrid (Spain)

P. Chavel, Institut d'Optique, CNRS (France)

K. Chalasinska-Macukow, University of Warsaw (Poland)

Eustace L. Dereniak, University of Arizona (United States)

A. Dieterlen, Université de Haute-Alsace (France)

M. Dennis, University of Bristol (United Kingdom)

A. Desyatnikov, Australian National University (Australia)

Y. Fainman, University of California (United States)

Ari T. Friberg, University of Eastern Finland (Finland), Aalto University (Finland), and Royal Institute of Technology (Sweden)

J. Galas, Institute of Applied Optics (Poland)

Enrique J. Kiko Galvez, Colgate University (United States)

G. Gbur, University of North Carolina (United States)

B. Grzegorzewski, Nicolaus Copernicus University (Poland)

Min Gu, Swinburne University of Technology (Australia)

S. Hanson, Technical University of Denmark (Denmark)

Yu. Kivshar, Australian National University (Australia)

M. Kolwas, Institute of Physics Polish Academy of Sciences (Poland)

O. Korotkova, University of Miami (United States)

Tim Lee, University of British Columbia (Canada), Vancouver Coastal Health Research Institute (Canada), BC Cancer Agency (Canada), and Simon Fraser University (Canada)

J. Mait, US Army Research Laboratory (United States)

I. Mokhun, Chernivtsi National University (Ukraine) 
G. Montemezzani, Université de Metz (France)

E. G. Mishchenko, University of Utah (United States)

M. Mishchenko, NASA Goddard Institute for Space Studies (United States)

Yoko Miyamoto, University of Electro-Communications (Japan)

S. Odoulov, Institute of Physics, National Academy of Sciences of Ukraine (Ukraine)

W. Osten, Universität Stuttgart (Germany)

M. Padgett, University of Glasgow (Scotland)

G. Pedrini, Universität Stuttgart (Germany)

V. Podolskiy, University of Massachusetts Lowell (United States)

P. Polyanskii, Chernivtsi National University (Ukraine)

Filippus S. Roux, CSIR National Laser Centre (South Africa)

T. Setala, Aalto University School of Science and Technology (Finland)

P. Slangen, Université de Liège (France)

C. Sheppard, IIT-Istituto Italiano di Tecnologia (Italy)

R. Silvennoinen, University of JoensuU (Finland)

M. Soskin, Institute of Physics, National Academy of Sciences of Ukraine (Ukraine)

T. Szoplik, University of Warsaw (Poland)

M. Tavassoly, University of Tehran (Iran)

Yasuo Tomita, University of Electro-Communications (Japan)

V. Vlad, University of Bucharest (Romania)

R. Vlokh, Institute of Physical Optics (Ukraine)

Wei Wang, Heriot-Watt University (United Kingdom)

J. Wyant, University of Arizona (United States)

Xinzheng Zhang, Nankai University (China)

D. Zimnyakov, Yuri Gagarin State Technical University of Saratov

(Russian Federation)

\section{Organizing Committee}

G. Bilyanin, Institute of Postdiploma Pedagogical Education (Ukraine) Sergey Kostykevych, Institute of Semiconductor Physics (Ukraine) Igor Mysevych, Arton Company (Ukraine)

V. Godovanyuk, Central Design Office (Ukraine)

T. Venkel, Chernivtsi National University (Ukraine)

V. Kramar, Chernivtsi National University (Ukraine)

S. Yermolenko, Chernivtsi National University (Ukraine)

C. Zenkova, Chernivtsi National University (Ukraine)

D. Burkovets, Chernivtsi National University (Ukraine)

Yu. Ushenko, Chernivtsi National University (Ukraine)

Ch. Felde, Chernivtsi National University (Ukraine)

Yu. Viktorovskaya, Chernivtsi National University (Ukraine)

M. Gavrylyak, Chernivtsi National University (Ukraine)

A. Arkhelyuk, Chernivtsi National University (Ukraine) 
N. Dominikov, Chernivtsi National University (Ukraine)

P. Maksimyak, Chernivtsi National University (Ukraine)

A. Maksimyak, Chernivtsi National University (Ukraine)

M. Gorsky, Chernivtsi National University (Ukraine)

A. Motrich, Chernivtsi National University (Ukraine)

L. Pidkamin, Chernivtsi National University (Ukraine)

A. Dubolazov, Chernivtsi National University (Ukraine)

A. Nehrych, Chernivtsi National University (Ukraine)

O. Konovchuk, Chernivtsi National University (Ukraine)

B. Tymochko, Chernivtsi National University (Ukraine)

A. Karachevtsev, Chernivtsi National University (Ukraine)

K. Kharitinova, Chernivtsi National University (Ukraine)

Yu. Galushko, Chernivtsi National University (Ukraine)

M. Strinadko, Chernivtsi National University (Ukraine)

\section{Session Chairs}

Plenary Session 1

Wei Wang, Heriot-Watt University (United Kingdom)

Oleg V. Angelsky, Chernivtsi National University (Ukraine)

Plenary Session 2

S. Hanson, Technical University of Denmark (Denmark)

S. Odoulov, Institute of Physics, National Academy of Sciences of Ukraine (Ukraine)

1 Informative Content of Statistical Optical Fields, Including Optical Chaos, Singular Optics, Polarization Optics and Coherence

M. Berry, University of Bristol (United Kingdom)

D. A. Zimnyakov, Saratov State University (Russian Federation)

J. Wyant, University of Arizona (United States)

E. Mishchenko, University of Utah (United States)

Tim Lee, University of British Columbia (Canada), Vancouver Coastal Health Research Institute (Canada), BC Cancer Agency (Canada), and Simon Fraser University (Canada)

I. Mokhun, Chernivtsi National University (Ukraine)

2 Optical Correlation Devices Based on Diffractive Optical Elements, Including Optical and Digital Holography, Fractal Optics, Optical Sensors

M. Alonso, Institute of Optics, University of Rochester (United States)

K. Bliokh, Australian National University (Australia) 
3 Optical Correlation Diagnostics, Interferometry and Microscopy of Rough Surfaces and Random Media

M. Dennis, University of Bristol (United Kingdom)

K. Kolwas, Institute of Physics, Polish Academy of Sciences (Poland)

A. Desyatnikov, Australian National University (Australia)

A. Bekshaev, I.I. Mechnikov National University (Ukraine)

4 New Applications of Correlation Optics in Biology and Medicine R. Silvennoinen, University of JoensuU (Finland) 


\section{Introduction}

The Eleventh International Conference on Correlation Optics continues the series of conferences with the same title held biannually at Chernivtsi National University (Ukraine) since 1993. More than 130 participants from 20 countries attended the conference, and more than 200 talks were presented.

This volume includes oral and poster contributions on the following topics:

1. Informative content of statistical optical fields, including optical chaos, singular optics, polarization optics and coherence;

2. Optical correlation devices on diffractive optical elements, including optical and digital holography, fractal optics and optical sensors;

3. Optical correlation diagnostics, interferometry and microscopy of rough surfaces and random media;

4. New applications of correlation optics in biology and medicine.

I am grateful to all participants of the conference, as well as to the members of the International Program Committee and the Conference Organizing Committee whose work provided high scientific value and organizing level of the conference.

Oleg V. Angelsky 
Proc. of SPIE Vol. 9066 906601-16

Downloaded From: https://www.spiedigitallibrary.org/conference-proceedings-of-spie on 26 Apr 2023 Terms of Use: https://www.spiedigitallibrary.org/terms-of-use 